\title{
PRE-PUBLICATION VERSJON
}

Citation: Enli, Gunn (20 17). New Media and Politics. Annals of International Communication Association (pages I-8).

Published online 28 Oct 2017.

http://www.tandfonline.com/doi/full// 0.1080/23808985.20 I 7.139225 I 


\section{New Media and Politics}

Media and politics have been defined as a symbiosis because they are mutually dependent on each other. Accordingly, current research trends are concerned with investigating how this symbiosis is developing and changing as a result of new media technologies. This article starts by discussing the term 'new media' before discussing four main research strands: political activism; political campaigning, political polarization, and political journalism. Strengths and weaknesses in these fields will be discussed, and the concluding remark suggests a vision for further research on new media and politics.

Keywords: new media, social media, activism, election campaigns, journalism, polarization

\section{'New media' - a new research agenda?}

Research on new media and politics has always been influenced by contemporary trends and hypes, while also informed by underlying continuous perspectives. The relation between media and politics is among the most traditional and voluminous fields in media and communication research. Politics and the media are interrelated to a degree that has been characterized as a symbiosis, almost to the point that politics is inseparable from communication (Strömbeck and Esser 2014). This symbiosis is crucial to study because it involves idealistic functions, such as informed democracy, deliberative debate, and empowerment of the citizens, but also feared effects such as polarization, echo chambers, propaganda, and 'fake news'.

'New media' is a historically relative term, and it has been used to define a range of different applications and communication technologies since the 1960s (Marvin 1988). Today, 'new media' has been defined as communication technologies that enable or facilitate user-touser interactivity and interactivity between users and information: and the main point in the definition is that the one-to-many model of traditional mass communication is challenged by the possibility of many-to-many communication via the Internet. Accordingly, new media has been expected to transform the ways we interact and communicate, and the term pinpoints epoch- 
making phenomena, related to a more encompassing landscape of social, technological and cultural change (Rice 1999, Manovich 2003; Lister et al. 2003).

The term's persistency might be explained by its non-specific, but intuitive meanings. The term 'new' is still relevant because the new forms and platforms emerging in the 1990s and 2000s continues to disrupt the established and institutionalized mainstream media, and thus challenged an existing field of research (Hartley et al. 2013:3). However, because of ambitions to be more specific and to reflect recent changes, the dominance of the term 'new media' has largely been replaced by a 'social media buzz,' resulting also in a preference for the term 'social media'. In the following, I will discuss four key strands in new media and politics research: 1) political activism; 2) political campaigns; 3) political polarization, and 4) political reporting.

\section{Political activism in new media}

Every new media technology seems to have brought with it a set of new expectations related to a revival of democracy, political activism, and the empowerment of the people in relation to the power elites. Throughout history, a key argument in idealist critique of the media power is that the audience should not be limited to receive media content, but also be able to participate in the production.

With new media, ordinary people gained access to the means of digital production, and the research field has generally been influenced by expectations of the empowering potential of new participatory formats. Further, the expectations of social media as a tool for social change were fuelled by phenomena such as the Arab Spring (Howard et al 2011; Eltantawy and Wiest 2011; Khondker 2011). A useful insight in these studies is that new digital tools were effective for organizing protests, but that social change also depends on a set of unrelated factors. Related key findings from studies of digital activism in the Middle East, is that social online networks facilitate organizations and protests (Larner 2010; Jansen 2010). Moreover, a body of research argue that Internet activism has imposed a 'communication revolution' in China, and suggests that it will increase and adapt to the changing forms of state control (Wallis 2011, Yang 2009; 2014; Han 2016). 
The academic interest in online activism is not limited to specific geo-political regions. Rather, the field includes case studies of political movements and activism in varied countries; for example Spain, Greece, Turkey, Azerbaijan, Singapore, South Africa, and the USA (Karpf 2012; Penney \& Dadas 2013; Bruns et al. (eds.) 2016; Bocsh 2017; Gerbaudo 2017). New media has expanded and the field of political activism, both empirically and theoretically (see Norris' (2007) argument about the field being USA-centric).

The impact of digital activism on politics is disputed, and while some studies points to the strengths and possibilities such as networked mobilization or the evolvement of "politics of visibility" that alters traditional identity dynamics (Milan 2015), other studies emphasize what they regard as weaknesses and limitations such as digital divide, and the difficulties of sustaining stable ties between activists (Van Laer and Van Aelst 2010). Moreover, while some scholars claim that low-level and low-risk 'slacktivism', or 'clicktivism', is nearly worthless, because the activities are incapable of achieving intended goals (Morozow 2011), other studies underline that even 'armchair activism' might be important and meaningful for the individuals and are legitimate political acts (Rotman et al. 2011; Halupka 2014).

A key question in these studies is to what degree new media serve as a public sphere, which enables online deliberation and thus has the potential to empower people. However, the normative ideals of a deliberative public sphere are fairly contradictory to the often spontaneous, fragmented, and emotional online engagement. The research in this field would benefit from more nuanced approaches to online political participation, and not least by acknowledging that there are diverging motivations, variations of involvement, and that there are blurring boundaries between political activism and entertainment in the age of 'pop politics'.

\section{The impact of social media on political campaigns}

Similar to how the 'Arab Spring' fuelled the first trend, the Obama election campaigns fuelled the second trend. This body of research has widely explored the rise of social media as campaign tool in western stable democracies, but also in new democracies (Bruns et al. 2016 
(eds.); Enli and Moe (eds.) 2015; Kreiss 2012; Stromer-Galley 2014; Graham et al. 2013).

The studies identify various contextual factors that explain candidate behaviour in social media; political systems (Enli and Skogerbø 2015; Gibson 2015), compulsory voting (Highfield and Bruns 2016), technological skills (Kreiss 2014; Kreiss and Jasinski 2016) incumbency advantage (Enli and Naper 2016) and economic resources (Gibson and McAllister 2015). Research on social media and election campaigns is for various reasons mostly designed as single-country case studies, and in spite of edited collections covering a variety of counties (Cluver et al. 2007; Bruns et al. 2016), there is a lack of thorough comparative and crossnational studies.

A key concern in this body of literature is the degree of interactivity between politicians and voters. The general finding is that politicians are reluctant to interact with other users; the more powerful the politicians are, and the more hierarchical the political culture, the less they interact with voters (Burgess and Bruns 2012; Graham et al. 2013; Kreiss 2014; Stromer-Galley 2014; Kalsnes et al. 2017). The studies are important evidence about how political candidates use new media to promote their candidacy, while they seldom or never engage in dialogue with the voters. Moreover, a key finding is that social media have contributed to increase the personalization of politics, also in party-centred political systems (Enli and Skogerbø 2015). In tandem with personalization of politics, studies of for example the US president Donald Trump's Twitter account, have demonstrated that social media is used by politicians to come across as authentic, and perform a role as rebellious (Ott 2017; Enli 2017).

The construction of the authentic candidate on social media is closely related to the rhetoric of populism, and one of the most urgent questions in the field is to what degree social media is a resource for populist politicians to present a fragmented ideology, and a channel to bypass editorial media. Engesser et al. (2016) has shown that social media is a suitable arena for populist communication, because of its preference for the polarized, simplified, and emotional. However, more empirical and qualitative research is needed to investigate the impact of new media on political campaigns, and to what degree social media is more suitable for populist rhetoric than more complex political rhetoric. 


\section{Political Polarization, Echo Chambers and Social Networks}

A third major concern in studies of new media and politics is the degree to which the recent user migration to online platforms contributes to political polarization through so-called 'echo chambers' and 'filter bubbles' (Pariser 2011). The discourse around 'echo chambers' has been driven by fear of political polarization and political extremism, and based on premises that new media offer users personalized and pre-selected information (Pasquale (2015;. Barberá 2015; Boutyline \& Willer 2016; Trilling, et al. 2016; Hong \& Kim 2016). Yet, an expanding body of research pinpoint that the fear might lack empirical rationale and that social filtering has always existed. In the literature, there are diverging findings, which demonstrates that new media in some cases might contribute to political polarization, but that it simultaneously exposes users to diverse content, including political opinions contradicting their own (Kwak et al. 2010; Wilson 2014; Banksy et al. 2015; Zuiderveen Borgesius et al. 2016; Trilling, Van Klingeren, \& Tsfati, 2016). The effect will always be relative and contextual, and dependent on individual user practises as well as factors outside the social media networks.

There are however also limitations in this body of research; First, a key weakness is that the majority of studies on political polarization originates in the US, where the political system is quite distinct both in a global context and in the context of western democracies. The US is for example a more polarized society than most European and Nordic democracies (Syvertsen et at 2014; Trilling, Van Klingeren, \& Tsfati, 2016). The field would benefit from more comparative studies, and studies which contextualises how various political systems impacts on the effects of new media on political polarization.

A second weakness is that the studies tend to be not only media-centric, but also Twittercentric, meaning that Twitter is overrepresented in studies of networked communication. This is evident in the many studies of the various functions of Twitter, including Twitter hashtags (Rambukkana (ed.) 2015; Bruns and Burgess 2015; Bruns et al. 2016; Enli and Simonsen 2017), Twitter typologies (Awan 2014; Bruns and Stiegliz 2013; Danescu-Niculescu-Mizil et al. 2011; Weller et al. 2014), and Big Data Twitter analysis. In spite of the insights into Twitter networks 
provided by these studies, their value would be even greater if they related more to the complexity of how users engage in politics online. There is a risk that the Twitter-centrism and preference for Big Data is limiting the research agenda in the field, and that more fruitful methods such as ethnography, research interviews, and textual analysis, are disregarded.

A key challenge in this strand is that there are ethical implications of tracking data in order to study users' political orientation. The preference for Twitter studies above Facebook studies is partly legitimated by the more public character of tweets than Facebook updates. Even though this might be right from the researchers point of view, it is an ethical challenge that the Twitter users are generally not aware that their accounts are being tracked, and seldom offered the opportunity to give their informed consent. Another methodological challenge is that, although more ethical, self-reporting surveys has the weakness of lacking reliability in studies of political polarizing. The complexity of users' exposure to online political content and the potential effect on political polarization is challenging to measure, but the field would benefit from drawing more on existing theories on media effect as well as longitudinal studies. We need to move beyond the Twitter-centrism and fascination for the newest features to investigate political polarization and 'echo chambers'.

\section{Political reporting in the age of the 'hybrid media system'}

Lastly, there is a trend in the field to increasingly acknowledge that new media is interrelated with old media, and that contemporary politics might relate to the 'new media logics', but that this is never isolated from the 'old media logics' (van Dijck and Poell, 2013; Chadwik et al. 2016:11). A key concept in this research strand is the 'hybrid media system', which refers to how new media is interconnected with old or mainstream media (Chadwick 2013).

Along the same lines, several studies have been concerned with 'intermedia agenda setting', with emphasis on how traditional agenda setting theory is challenged by new media. In a hybrid media system, the agenda setting process is more complex, and several studies have argued that the process is characterized by an inter-dependency between traditional mass media and new media (Broersma and Graham 2012; Wallsten 2015; Oates and Moe 2016; Wells et al. 
2016). However, the 'hybrid media system' seems to only in a limited degree be reflected in the methodological strategies. For example, studies that compare datasets from social media with news stories in mainstream media in order to map the manifestations of quotes from social media in news stories, fails to grasp the impact of social media on news production which are not manifested in the output.

A second approach to the influence of new media on political reporting is studies of user-generated content in the context of news production. In particular, studies have focused on the impact of new media on aspects of news production such as gatekeeping (Singer 2014), source gathering (Livingstone \& Bennett 2003), and news criteria (Carpenter 2010). Key findings in these studies are that while some practises are continued, like the preference for official sources, online citizen journalism has expanded the diversity of content and available information, and gatekeeping processes has become a two-step process where the editors' decisions are followed by users' decision to share the news (Singer 2014; Kümpel 2015). Through sharing and commenting, users will contribute to the political reporting, and themselves act as secondary gatekeepers with influence on how the news is understood and contextualized.

Research on user-comments has documented that political controversial issues are most often commented on, and that users who commented tended to be more politically to the right than average users, while the readers of the comments were largely unaware of this bias (Houston, Hansen, \& Nisbett 2011; Tenenboim \& Cohen, 2013; Friemel \& Dötsch 2015). This calls for not only an inclusion of the comments sections in studies of news journalism, but also studies about how news stories are interpreted and re-framed in social media. Political reporting is explicitly and implicitly influenced by user engagement and interactivity, and another fruitful research agenda would be to study new agents in news production, and to explore the dynamic between political reporting, user engagement, and algorithms.

In context of the recent debates about 'fake news' and decline in media trust, it would be relevant to study networked journalism practises (Heinrich 2011; Russell 2015). The classic newsroom studies needs to be rethought, in order to reflect recent changes and also to include 
the new actors. A key question is to what degree the norm of objectivity and impartiality are under pressure as a result of new players and the logics of clicks and sharing. In order to unpack the complexity of the contemporary production and distribution of political news it would be useful to combine ethnography and interviews with critical analysis of the mechanisms of algorithms (boyd et al. 2014; Shorey and Howard 2016).

\section{Dilemmas in future new media and politics research}

The term 'new media' will seem even more anachronistic in future research and 'new media' even defined as the internet are constantly changing, but the impact of disruptive digital technologies on how politics work will nevertheless continue to be important to explore. Based the above discussion of recent research on new media and politics, I will present three suggestions for future research, and pinpoint the most prevailing contemporary dilemmas in the field.

First, studies of new media and politics should move beyond the most hyped events, such as the Arab Spring, the Obama campaigns, and Trump's use of Twitter, and include also analysis of more mundane and less high-profiled empirical material. Of course, it is both legitimate and fruitful to study the prominent and momentous events, because they have public interest, as new evidence in the continuous development of the relationship between media and politics (see also Karpf p. 2017, p. 205). However, the research should not be driven only by trends and events, but also by ambitions to analyse the historical lines, and I would argue that longitudinal studies that goes beyond single epic events is needed. The key dilemma here is that researchers will often find it more rewarding to publish on events-driven research rather than undertake the, often more time-consuming, longitudinal studies.

A second suggestion is to expand the cultural-geographic horizon, so that we avoid the US centric - or Western democracy centric - limitation in the field of new media and politics. Although the US if often a point of reference in studies of how the media influences politics, we should not overlook how politics in other parts of the world is 
perhaps even more vulnerable to media changes. I would recommend a higher priority of research on the relationship between politics and new media in authoritarian regimes, new democracies, or hybrid systems. The key dilemma related to this point is that scholars are restricted by the path-dependency in the field, and that the existing US-centric literature is likely to further consolidate the focus of US politics, rather than inspire scholars to chose the path less travelled.

Third, a key aspect of the relation between media and politics is the question of the symbiosis, and to what degree new media changes the power-balance between politicians and the media. New media challenges the authority of mainstream media, and enables politicians and political activists to use alternative media channels for communication. To what degree will this development, on the one hand, dissolve the symbiosis, and provide the politicians with channels for political propaganda, and on the other hand, reduce the citizens' trust in the media as a source to political information, involvement, and empowerment (see, for example, Thorson 2016). These questions are increasingly important in the age of 'fake news', 'bots', and 'artificial intelligence', and we need to, again be aware of the dilemmas of being obsessed with a hyped phenomena, but also be innovative and interdisciplinary enough to uncover important changes in the relationship between media and new politics, and how it influences the conditions for political debate and democracy. 


\section{References}

Awan, I. (2014). Islamophobia and Twitter: A typology of online hate against muslims on social media. Policy \& Internet, 6(2), 133-150.

Barberá, P. (2015). "Birds of the Same Feather Tweet Together: Bayesian Ideal Point Estimation Using Twitter Data.” Political Analysis 23(1):76-91.

Bakshy, E., Messing, S., \& Adamic, L. (2015). Exposure to ideologically diverse news and opinion on Facebook. Science, 58(4), 707-731.

Bocsh, T. (2017): Twitter activism and youth in South Africa: the case of \#RhodesMustFall, Information, Communication \& Society Volume 20, 2017 - Issue 2

Boutyline, A., \& Willer, R. (2016). The Social Structure of Political Echo Chambers: Variation in Ideological Homophily in Online Networks. Political Psychology.

Broersma, M., \& Graham, T. (2012). Social media as beat: Tweets as a news source during the 2010 British and Dutch elections. Journalism Practice, 6(3), 403-419.

Bruns, A. (2012). How long is a tweet? Mapping dynamic conversation networks on Twitter using Gawk and Gephi. Information, Communication \& Society, 15(9), 1323-1351.

Bruns, A., \& Burgess, J. (2012). Researching news discussion on Twitter: New methodologies. Journalism Studies, 13(5-6),

Bruns, A., \& Stieglitz, S. (2013). Towards more systematic Twitter analysis: metrics for tweeting activities. International Journal of Social Research Methodology, 16(2), 91-108.

Bruns, A., Highfield, T., \& Burgess, J. (2013). The Arab Spring and social media audiences:

English and Arabic Twitter users and their networks. American Behavioral Scientist, 57(7), 871898.

Bruns, A., \& Burgess, J. (2015). Twitter Hashtags from Ad Hoc to Calculated Publics. In N. Rambukkana (ed.), Hashtag Publics: The Power and Politics of Discursive Networks (1st ed., pp. 13-27). New York: Peter Lang.

Bruns, A., Moon, B., Paul, A., \& Münch, F. (2016). Towards a typology of hashtag publics: A large-scale comparative study of user engagement across trending topics. Communication Research and Practice, 2(1), 20-46.

boyd, d., Levy, K., \& Marwick, A. (2014). The networked nature of algorithmic discrimination. In S. P. Gangadharan, V. Eubanks, \& S. Barocas (Eds.), Data and discrimination: Collected essays (n.p.). Washington, DC: Open Technology Institute and the New America Foundation.

Carpenter, S.: A study of content diversity in online citizen journalism and online newspaper articles. New Media \& Society Vol 12, Issue 7, pp. 1064 - 1084. 
Chadwick, A. (2013). The hybrid media system: Politics and power. Oxford University Press.

C., Gamon, M., \& Dumais, S. (2011, March). Mark my words!: linguistic style accommodation in social media. In Proceedings of the 20th international conference on World wide web (pp. 745-754). ACM.

Hong, S., \& Kim, S. H. (2016). Political polarization on twitter: Implications for the use of social media in digital governments. Government Information Quarterly, 33(4), 777-782.

Houston, B.J, G. J. Hansen, \& G. S. Nisbett (2011): Influence of User Comments on Perceptions of Media Bias and Third-Person Effect in Online News. Electronic News. Vol 5, Issue 2, pp. 79 - 92

Eltantawy, N., \& Wiest, J. B. (2011). The Arab spring. Social media in the Egyptian revolution: reconsidering resource mobilization theory. International Journal of Communication, 5, 18.

Engesser, S., Ernst, N., Esser, F., \& Büchel, F. (2016). Populism and social media: how politicians spread a fragmented ideology. Information, Communication \& Society, 1-18.

Enli, G. S., \& Skogerbø, E. (2013). Personalized campaigns in party-centred politics: Twitter and Facebook as arenas for political communication. Information, Communication \& Society, $16(5), 757-774$.

Enli, G. \& Moe, H. (eds.). (2015). Social Media and Election Campaigns: Key Tendencies and Ways Forward. New York: Routledge

Enli, G. \& Naper, A. (2016). Social Media Incumbent Advantage: Barack Obama's and Mitt Romney's Tweets in the 2012 U.S. Presidental Election Campaign. In A. Bruns, G. Enli, E. Skogerbø, A. O. Larsson \& C. Christensen (eds) (2016) The Routledge Companion to Social Media and Politics (pp. 364-377). New York: Routledge

Enli, G. (2017): Twitter as arena for the authentic outsider: exploring the social media campaigns of Trump abd Clinton in the 2016 presidential election. European Journal of Communication. Vol. 32. Issue 1. Pp. 50-61.

Enli, G. \& C. Simonsen (2017): 'Social media logic' meets professional norms: Twitter hashtags usage by journalists and politicians. Information, Communication \& Society. Online first.

Friemel, T. N., \& Dötsch, M. (2015). Online Reader Comments as Indicator for Perceived Public Opinion. In M. Emmer \& C. Strippel (Eds.), Kommunikationspolitik für die digitale Gesellschaft. .Pages 151-172.

Gerbaudo, P. (2017): Social media teams as digital vanguards: the question of leadership in the management of key Facebook and Twitter accounts of Occupy Wall Street, Indignados and UK Uncut, Information, Communication \& Society Volume 20, Issue 2 
Gibson, R. K. (2015). Party change, social media and the rise of 'citizen initiated'campaigning. Party politics, 21(2), 183-197. doi.org/10.1177/1354068812472575.

Gibson, R. K., \& McAllister, I. (2015). Normalising or equalising party competition? Assessing the impact of the web on election campaigning. Political Studies, 63(3), 529-547.

doi.org/10.1111/1467-9248.12107.

Graham, T., Broersma, M., Hazelhoff, K., \& van 't Haar, G. (2013). Between

Broadcasting Political Messages and Interacting With Voters. Information,

Communication \& Society, 16(5), 692-716. doi.org/10.1080/1369118X.2013.785581.

Halupka, M. (2014). Clicktivism: A systematic heuristic. Policy \& Internet, 6(2), 115-132. DOI: 10.1002/1944-2866.POI355.

Hartley, J., Burgess, J., \& Bruns, A. (2013). Introducing Dynamics. A Companion to New Media Dynamics, 1-11.

Heinrich A (2011) Network Journalism: Journalistic Practice in Interactive Spheres. London: Routledge.

Highfield, T., \& Bruns, A. (2016). Compulsory Voting, Encouraged Tweeting? Australian Elections and Social Media. In A. Bruns, G. Enli, E. Skogerbø, A. Larsson \& C. Christensen (eds.) The Routledge Companion to Social Media and Politics (pp. 338-350). New York: Routledge.

Howard, P. N. (2011). The Arab spring's cascading effects. Pacific Standard, 23.

Jackson, N., \& Lilleker, D. (2011). Microblogging, constituency service and impression management: UK MPs and the use of Twitter. The Journal of Legislative Studies, 17(1), 86-105.

Jansen, F. (2010) Digital activism in the Middle East: mapping issues networks in Egypt, Iran, Syria and Tunisia. Knowledge Management for Development Journal. Volume 6, issue 1.

Kümpel, A. S., V. Karnowski, \& T. Keyling (2015): News Sharing in Social Media: A Review of Current Research on News Sharing Users, Content, and Networks. Social Media + Society. Vol 1, Issue 2

Yang, G. (2014): Internet Activism \& the Party-State in China, Daedalus, Spring 2014, Vol. 143, No. 2 , Pages: 110-123.

Karpf, D. (2012) The MoveOn Effect: The Unexpected Transformation of American Political Advocacy.

Karpf, D (2017) Digital politics after Trump. Annals of the International Communication Association. 41;2, 198-202.

Wallis, C. (2011): New Media Practices in China: Youth Patterns, Processes, and Politics International Journal of Communication 5, 406-436 
Khondker, H. H. (2011). Role of the new media in the Arab Spring. Globalizations, 8(5), 675679 .

Kreiss, D. (2012). Taking our country back: The crafting of networked politics from Howard Dean to Barack Obama. Oxford University Press.

Kreiss, D. (2014). Seizing the moment: The presidential campaigns' use of Twitter during the 2012 electoral cycle. New Media \& Society, 18(8), 1473-1490.

Kreiss, D. \& Jasinski, C. (2016) The Tech Industry Meets Presidential Politics: Explaining the Democratic Party's Technological Advantage in Electoral Campaigning, 2004-2012. Political Communication 33(4), 1-19.

Kwak, H., Lee, C., Park, H., \& Moon, S., (2010). What is Twitter, a social network or a news media? Proceedings of the 19th International Conference on World wide web, April 26-30, 2010, Raleigh, NC.

Lister, M. (2003). New media: A critical introduction. Taylor \& Francis.

Manovich, L. (2003). New media from Borges to HTML. The new media reader, 1, 13-25.

Marvin, C. (1988). When old technologies were new: Thinking about communications in the late 19th century. New York: Oxford University Press

Morozov, E. (2011). The net delusion: How not to liberate the world. Penguin UK.

Oates, S., \& Moe, W. W. (2016). Donald Trump and the 'Oxygen of Publicity': Branding, Social Media, and Mass Media in the 2016 Presidential Primary Elections. Paper prepared for the American Political Science Association Annual Meeting 2016

Ott, B. L. (2017). The age of Twitter: Donald J. Trump and the politics of debasement. Critical Studies in Media Communication, 34(1), 59-68. doi.org/10.1080/15295036.2016.1266686.

Pariser, Eli. 2011. The Filter Bubble: What the Internet Is Hiding from You. Penguin UK.

Pasquale F (2015). The black box society: The secret algorithms that control money and information. Cambridge: Harvard University Press.

Penney J. \& C. Dadas (2013): Re)Tweeting in the service of protest: Digital composition and circulation in the Occupy Wall Street movement. New Media \& Society. Vol 16, Issue 1, pp. 74 $-90$

Rambukkana, N. (2015). Hashtags as Technosocial Events. In N. Rambukkana (ed.), Hashtag Publics: The Power and Politics of Discursive Networks (pp. 1-10). New York: Peter Lang.

Rice, R. E. (1999). Artifacts and paradoxes in new media. New Media \& Society, 1(1), 24-32 
Rotman, D., Vieweg, S., Yardi, S., Chi, E., Preece, J., Shneiderman, B., ... \& Glaisyer, T. (2011, May). From slacktivism to activism: participatory culture in the age of social media. In CHI'11 Extended Abstracts on Human Factors in Computing Systems (pp. 819-822). ACM..

Russell A (2015) Networked journalism. In: Witschge T, Anderson CW, Domingo D, (eds) The Sage Handbook of Digital Journalism. New York: SAGE, pp. 149-163

Shorey, S., \& Howard, P. (2016). Automation, Algorithms, and Politics| Automation, Big Data and Politics: A Research Review. International Journal of Communication, 10, 24.

Singer, J.B: User-generated visibility: Secondary gatekeeping in a shared media space. New Media \& Society. Vol 16, Issue 1, pp. 55 - 73

Stromer-Galley, J. (2014). Presidential campaigning in the Internet age. Oxford University Press.

Strömbäck, J., \& Esser, F. (2014). 16 Mediatization of politics: transforming democracies and reshaping politics. In Knut Lundby (ed.), Mediatization of Communication (pp. 375-400). Walter de Gruyter GmbH \& Co KG.

Trilling, D., van Klingeren, M., \& Tsfati, Y. (2016). Selective Exposure, Political Polarization, and Possible Mediators: Evidence From the Netherlands. International Journal of Public Opinion Research, edw003.

Thorson, E. (2016): Belief Echoes: The Persistent Effects of Corrected Misinformation, Political Communication 33.3, 460-480.

Van Dijck, J., \& Poell, T. (2013). Understanding Social Media Logic. Media and Communication, 1(1), 2-14.

Van Laer \& Van Aelst (2010): Internet and social movement action repertoires. Opportunities and limitations. Information, Communication \& Society.

Wallsten, K. (2015). Non-Elite Twitter Sources Rarely Cited in Coverage. Newspaper Research Journal, 36(1), 24-41..

Willson, M., 2014. “The politics of social filtering.” Convergence 20, 218-232.

Weller, K., Bruns, A., Burgess, J., Mahrt, M., \& Puschmann, C. (eds.) (2014). Twitter and Society. New York: Peter Lang. 
Wells, C., Shah, D. V., Pevehouse, J. C., Yang, J., Pelled, A., Boehm, F., ... \& Schmidt, J. L. (2016). How Trump drove coverage to the nomination: Hybrid media campaigning. Political Communication, 33(4), 669-676.

Zuiderveen Borgesius, F. J., and Trilling, J. Möller, B. Bodó, and C. de Vreese, and N. Helberger. (2016): "Should we worry about filter bubbles?". Internet Policy Review 5 (1). 